\title{
Dimitrije Djordjevic, 1922-2009
}

My dear friend and mentor Dimitrije Djordjevic, one of the most distinguished scholars of Serbian and Balkan history, died on 5 March 2009. He was born on 27 February 1922 in Belgrade, the scion of a prominent family that had produced more than a few ambassadors, generals, and government ministers. Had history not decisively intervened, Dimitrije would likely have led a privileged and political life. But with the German invasion and destruction of Yugoslavia in 1941, Dimitrije for a time became a personification of the Yugoslav tragedy. Having been imbued with a strong sense of democratic patriotism, he joined the Youth Command of the Cetnik resistance movement led by Draža Mihailović. After some months operating in the mountains, Dimitrije was arrested by the Gestapo in October 1942 and interned at the notorious Mauthausen camp in Austria. While fortunate to survive this experience, he was quickly rearrested in November 1945 by the secret police of the new Tito regime in the reconstructed Yugoslavia. Following a widely watched trial, he was sentenced to four years imprisonment for having been in the wrong resistance movement during the war and for agitating for democracy at its end. After another grueling prison term, Dimitrije was finally released in a general amnesty in 1947. Because he was now labeled a reactionary, he was prevented from resuming his studies until 1950; he finally completed his $\mathrm{PhD}$ in 1962 . Unable to teach for political reasons, Dimitrije concentrated on research and writing. His talent was quickly recognized, and a group of senior historians arranged for him to be appointed to a research position in the Institute of History at the Serbian Academy of Arts of Sciences. Here he was able to firmly establish his reputation as a gifted and prolific scholar and was also able to play a leading role in establishing professional contacts between Yugoslav historical circles and the west. Once allowed to travel, Dimitrije was also finally able to realize his dream of teaching. In 1966 he taught a course in Balkan history at Cambridge University and then was brought to the University of California, Santa Barbara, in 1970, where he spent the rest of his distinguished professional career.

Dimitrije authored, coauthored, or edited a total of twenty-five books and literally hundreds of articles and reviews in leading historical journals in North America and Europe. He organized and participated in scores of national and international conferences. While his principal research concentrated on nineteenth- and twentieth-century Serbian history, he ultimately studied and wrote about all of the Balkan peoples and states. He had a remarkable ability to present local history in the context of broader Balkan and European history. Among other contributions, he published two important short studies, one on Serbia's Adriatic policy and the other on Milovan Milovanović, a prominent Serbian foreign minister.

Dimitrije's best and probably most enduring published works include his seminal study of the Serbian-Austrian customs war and his sensitive autobiography, Scars and Memory: Four Lives in One Lifetime (1997), which constitutes an important contribution to the literature of World War II and the immediate postwar order in Europe. While he received many awards, Dimitrije's proudest moments included his election to the Serbian Academy of Arts and Sciences, Serbia's foremost learned society in 1985, and the presentation of his festschrift entitled Scholar, Patriot, Mentor produced on the occasion of his retirement in 1991. Many of his nineteen PhD students and nine MA students, whom he lovingly referred to as his "Balkan Family," were able to contribute to the volume. In retirement Dimitrije continued to research and publish, even as he agonized over the tragedy of the wars of the destruction of the second Yugoslavia. While always maintaining a deep affection for his homeland, his sense of honor, decency, and fairness allowed him to reject the chauvinistic nationalism that overwhelmed some of his Serbian colleagues in the 1990s. He remained the voice of reason, the definitive gentleman and scholar.

I will miss his devotion to the life of the mind, his sage advice, and his good humor. I will miss, as well, our long conversations over slivovitz and the occasional cigar, which Dimitrije maintained provided us with a necessary sense of balance after a hard-fought

Slavic Review 69, no. 4 (Winter 2010) 
game of tennis. He will be missed by his loving wife, Nan, and by his extended bicontinental family. He will be missed by his students, his friends, his profession, as well as by all of those in his two countries who continue to hope and strive for enduring peace and justice in the Balkans.

BERND J. FISCHER

Indiana-Purdue University, Fort Wayne June 2010 